\title{
Vascular Endothelium
}

National Cancer Institute

\section{Source}

National Cancer Institute. Vascular Endothelium. NCI Thesaurus. Code C13053.

The layer of simple squamous epithelial tissue that lines the luminal surface of the entire circulatory system. 